\title{
Origin and development of avian skeletal musculature
}

\author{
Madeleine KIENY, Annick MAUGER, A. CHEVALLIER, Marie-Paule PAUTOU
}

Unité associée au CNRS 682 "Morphogenèse expérimentale ", Département de Biologie, Université Joseph Fourier, B.P. 53X, 38041 Grenoble Cedex, France.

Summary. Experimental studies have shown that the myogenic stem cells in birds migrate from the somite into the lateral plate mesoderm, where they later differentiate into muscle cells. Muscles being made up of myocytes and connective tissue cells, the interactions between these two types of cells of different embryological origins have been considered during the development of the musculature. In particular, our purpose was to focus on the genesis of the spatial organization of the musculature; we have taken advantage in this field of research of an embryological muscular dysgenesis in which the muscles lose their patterning.

\section{Introduction.}

The question of the origin and development of the musculature in tetrapods has been a longstanding problem (Fischel, 1895). During the last decades, this problem gained new interest due to several groups of investigators, who mostly used the avian limb as an experimental model, because of the relative ease with which microsurgery can be performed in avian embryos.

This review deals with two problems related to muscle development: 1) the specification of the muscle cells themselves, 2) the pattern formation, i.e., the process whereby the spatial organization and differentiation of the myogenic cells are achieved.

\section{Specification of the muscle cells.}

While it has been well established that, in the limbs, the skeleton and the dermis arise from the somatopleural mesoderm, it was not clear whether the musculature is of somatopleural or somitic origin. Historically there have been two different views on the nature of the cell population of the early limb bud. For some (Caplan and Koutroupas, 1973), the limb bud was constituted by a homogeneous population of mesodermal cells, the cellular differentiation of which was 
controlled by environmental cues. For others (Dienstman et al., 1974), a muscle cell lineage was already established when the limb bud bulged out. Experimental techniques using the chick-quail marker system advocated by Le Douarin and Barq (1969), confirmed the correctness of the lineage view. The evidence came from a crucial experiment which consisted in exchanging the somitic mesoderm at the wing level between the two species (Chevallier et al., 1976 ; Christ et al., 1974). It demonstrated that the muscle cells are derived from the somites and that they constitute a cell line different from those of other limb bud cells (Kieny, 1980). Because quail cells are endowed with a permanent nucleolar marker and thus can be distinguished from chick cells, the fate of the heterospecifically grafted somitic cells could be followed over a long period of time in ovo, namely from the somito-somatopleural migration of undifferentiated cells ( 2 days) to the differentiation of myofibers and their satellite cells (20 days).

Heterospecific somite exchange. - The orthotopical exchange of chick somitic tissue with quail somitic tissue revealed that the migration of somitic cells starts at stage $14 \mathrm{HH}$ (Hamburger and Hamilton, 1951) in the wing region (Chevallier, 1978; Jacob et al., 1978) and at stage $16 \mathrm{HH}$ in the leg region (Jacob et al., 1979). Leaving the ventro-lateral edge of the dermo-myotome, they move straight across from the somite towards the limb territory, before the limb bud bulges out. They are immediately involved in a coordinated limb development programme. While the limb bud is growing out, the somite-derived cells are, at first, haphazardly distributed within the limb bud mesoderm ; later they gather in the dorsal and ventral premuscular masses (fig. 1) (Newman et al., 1981) and, from there, are distributed in the individuating muscles (Kieny and Chevallier, 1980). The muscle arrangement is specific to each wing segment (upper arm forearm - hand), and does not differ from that of the corresponding segment in the control wing. Each anatomical muscle appears as a composite structure; the muscle cells (fig. $2 \mathrm{e}-\mathrm{j}$ ), i.e. myoblasts, myotubes, myofibres and satellite cells, are of somitic origin, while the intramuscular connective tissue, the epimysial envelope and the tendons (fig. $2 f$ ) are of somatopleural origin. It must be noted that the smooth muscle cells in the wing are also of somatopleural origin (Kieny et al., 1979).

Destruction of the somite source of myogenic ce/ls. - When the brachial somitic mesoderm is destroyed by local X-irradiation (fig. 2a), before the mediolateral migration of the myogenic cells has begun, a wing develops which completely lacks muscles (fig. $2 b-d$ ), but is temporarily equipped with tendons, particularly the distal autopodial ones (Chevallier et al., 1978; Kieny and Chevallier, 1979). Nerves penetrate into these muscleless wings. Their major trunks follow normal routes inside the connective tissue, but the penultimate branches to individual muscles are missing (Lewis et al., 1981). A similar abortive distribution of the final branches holds for the vasculature (unpublished data)

\section{Pattern formation.}

Descriptive study. - Before discussing the mechanisms whereby cells become spatially arranged, we shall consider the formation of the musculature. 

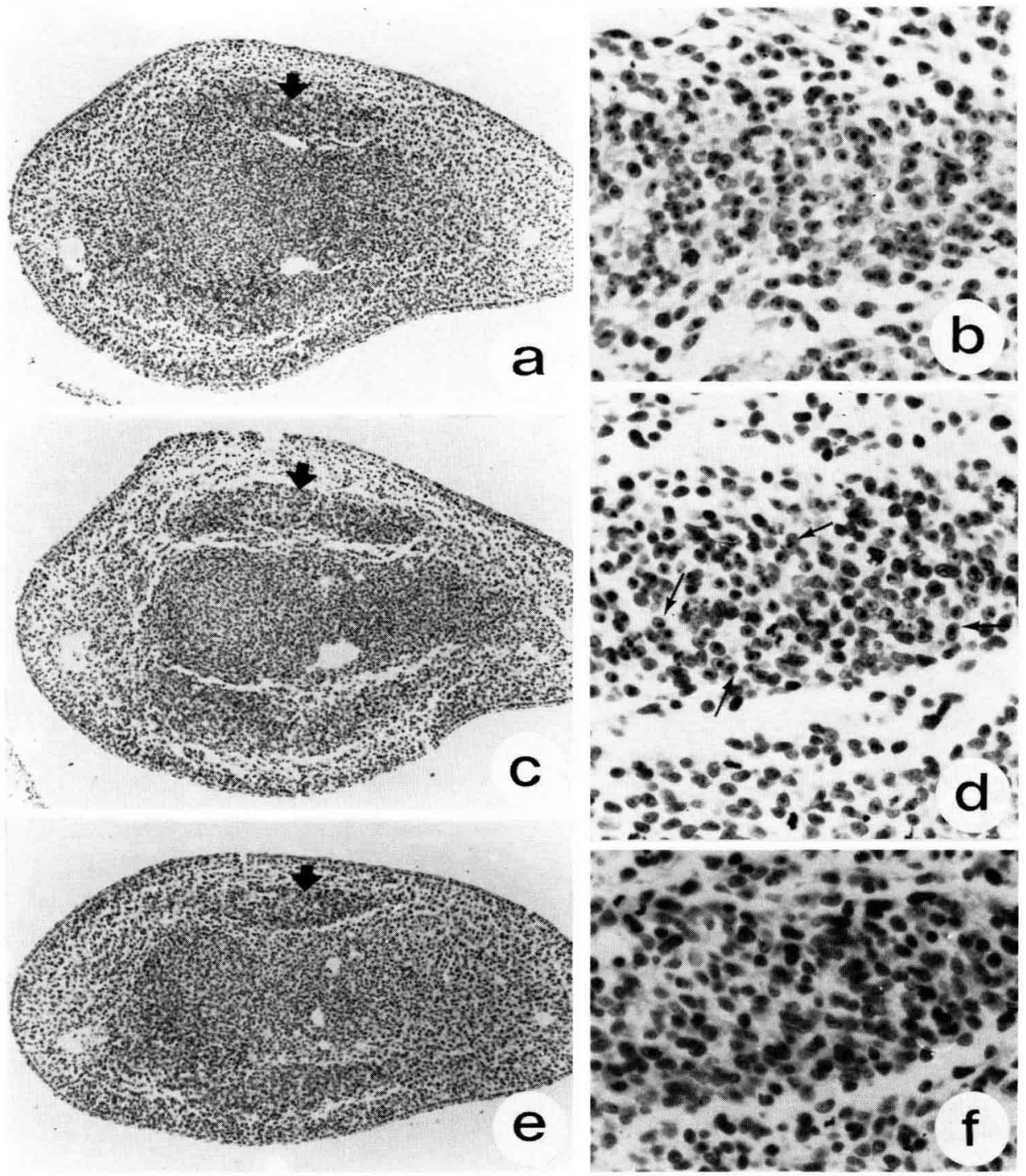

FIG. 1. - General views and details of the dorsal premuscular mass (large arrow) in transverse sections through the forearm of a 4.5-day quail embryo wing $(\mathrm{a}, \mathrm{b})$, a 5 -day chick embryo wing after a heterospecific chick/quail somite exchange experiment (c, d) and a normal 5-day chick embryo wing $(\mathrm{e}, \mathrm{f})$. In figure $d$, the arrows point to the quail cells that originated from the grafted somitic quail mesoderm.

The first morphological indication of muscle structure in the limbs is the formation, at stage 23-24 HH (4 days of incubation), of premuscular masses dorsal and ventral to the chondrogenic core (fig. 1). Particular attention was given to the zeugopodial [forearm (Shellswell and Wolpert, 1977) and lower leg (Pautou et al., 1982)] musculature because of the multitude of the muscles. The progressive individuation of these muscles starts at about 5 days of incubation in 


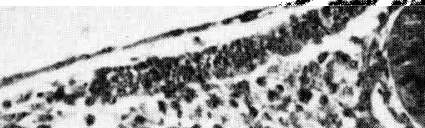

ind
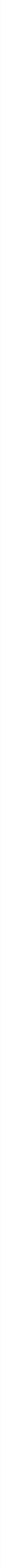

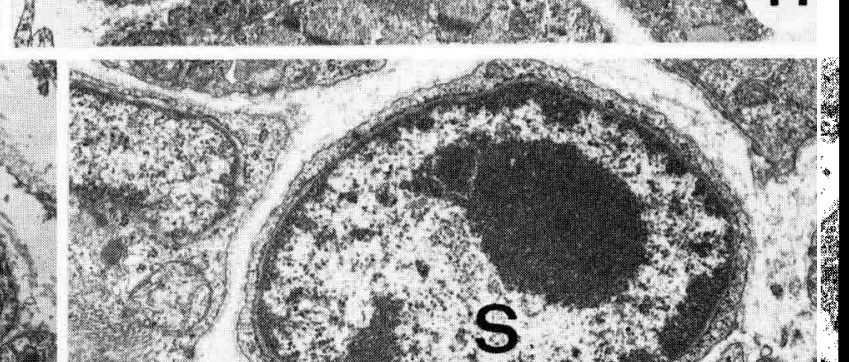

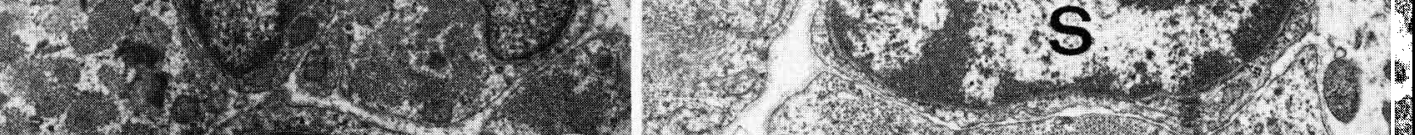
W 
the chick embryo. The dorsal and ventral premuscular blocks undergo a series of subdivisions. The clefts, which form as a slight decrease in cell density, do not appear at random, but in a very precise chronogical sequence. As the last splittings occur, changes in the size and location of muscles are brought about, so that at about 7.5 days of incubation the zeugopodial muscle patterns are laid down. Recent observations (unpublished data) show that the differentiation programme of the myocytes, namely multinucleation and myofrillogenesis, takes place regardless of the splitting programme.

Role of connective tissue. - Since the skeletal muscle cells originate from the somites, the question arises as to how the discrete muscles are formed and how their pattern is specified, hence as to the respective activities of the somitederived cells and of the somatopleural cells in muscle patterning. There is clear evidence that muscle specificity does not reside in the myogenic cells. The information on spatial arrangement is somehow contained in the limb, probably in the connective tissue of the premuscular masses. This has been demonstrated by the following experiments. Somitic mesoderm from any part of the cephalocaudal axis, such as the neck, flank or leg region, when grafted in place of the brachial somite row, gives rise to perfectly normal wing muscles (Chevallier et al., $1976,1977)$. Thus, all precursor muscle cells contained in the somites and even in the somitomeres (Noden, 1986) are equivalent along the cephalocaudal axis. In this respect they are unlike the sclerotomal and dermatomal components of the somite (Kieny et al., 1972). Myogenic cells which have already assembled inside the premuscular masses are still able to express the same organogenetic potentialities as the somitic myogenic precursor cells and are still indifferent regarding their region-specific determination (Mauger and Kieny, 1980). Even, myogenic cells issued from brachial somites brought in contact for about 2 days with chick pelvic limb mesenchyme and grafted back in place of brachial somites, still act like somitic cells and remain passive partners.

Other investigations were aimed at determining the duration of the organizing role of connective tissue and of the responsiveness of the mononucleated myocytes. They showed 1) that the muscle-cell organizing activity of the muscular connective tissue cells is of short duration and does not persist beyond the end of the splitting programme (Chevallier and Kieny, 1982);2) that only

FIG. 2 a to $\mathrm{d}$. - I/lustration of the absence of wing muscles after the destruction of the somitic source of the myogenic cells. Cross section (a) through the brachial region of a chick embryo $24 \mathrm{~h}$ after $X$-irradiation of its right-handed somitic mesoderm which is almost totally destroyed. Under these experimental conditions, on the irradiated side, a wing completely lacking muscles develops (c, d : about $100 \mu \mathrm{m}$ separate the two sections passing through the forearm). Compare with the normally musc/ed contralateral forearm (b).

e,f. - Illustration of 10.day forearm ( $\mathrm{f}$ ) and 18-day hand (e) heterospecific muscles after the replacement of chick wing-level somitic mesoderm by quail somitic mesoderm taken at the wing (e) or the leg (f) level. The implanted quail cells (arrows) are found exclusively in the muscles $(M$ ) where they constitute the myocyte population. $T$ tendon constituted by chick cells.

$\mathrm{g}$ to $\mathrm{j}$. - The somitic myogenic cell lineage also comprises the myosatellite cells (S). Species identification of satellite cells in 1-day quail $(\mathrm{g})$, in 20-day embryonic chick (i), and in cross sections of experimentally created bispecific muscles $(h, j)$, in which the myofiber nuclei are of quail origin. The specific feature of the quail muscle satellite cell is a centrally located patch of clumped chromatin. The satellite cells in the 20 -day embryonic chick/quail heterospecific extensor muscle show that their nuclear morphological criteria are of quail and not of chick type. 
myogenic cells that have completed somito-somatopleural migration respond to the influence of the muscular connective tissue of the limb anlage (Chevallier and Kieny, 1982) ; 3) that the responsiveness of the myogenic cells is not linked to their mononucleated state. Embryonic myoblasts and, even more so, satellite cells, do not represent equivalent populations as to their capacity to participate in muscle ontogeny; only the population of young myoblasts is competent (Chevallier et al., 1987).

Finally, the connective tissue cells are not only responsible for the spatial region-specific organization of the muscles, but they also control the course of the differentiation of the muscle cells. Indeed, the differentiation of quail multinucleated myocytes among chick endo- and perimysial fibroblasts evolve in accordance with chick timing (Armand et al., 1983).

\section{Defects in muscle development.}

In order to gain more insight into the mechanisms by which non-muscle cells control the process of muscle patterning, we investigated the embryology of a muscular disorder in fowl, the recessive crooked neck $d$ warf ( $\mathrm{cn} / \mathrm{cn}$ ) mutation that is lethal in homozygous conditions (Asmundson, 1945). A developmental analysis of the lower leg musculature of the siblings, where hypoplasia was particularly conspicuous, revealed that, up to 7 days of incubation, the splitting programme proceeded normally, i.e. in the same way as in a normal strain (Pautou et al., 1982). But thereafter, in about $25 \%$ of the siblings, the already individuated muscles fused into a single mass. Fusion proceeded in a well-ordered and constant sequence (Kieny et al., 1983), starting at 7.5 days in the central area of the posterior muscles (fig. $3 a, b$ ) and progressively involving the other posterior and anterior muscles (fig. $3 \mathrm{~h}, \mathrm{i}$ ). Thus the mutation interferes only with the maintenance of the muscle pattern, and not with its formation.

FIG. 3. - Hereditary muscular disorder in the crooked neck dwarf mutation ( $\mathrm{cn} / \mathrm{cn})$, characterized by a lack of muscular organization.

a, b. - Posterior muscle structures of the lower leg at 7.5 days of incubation in normal (a) and mutant (b) siblings. Notice the disappearance of the spaces (arrow) between most of the flexor muscles in the mutant.

c, d. - Longitudinal view (detail, in d) of a flexor muscle from the contralateral leg to that illustrated in figure $b$, showing that myogenesis seems to have proceeded normally: straight multinucleated myotubes are present.

e to g. - Effects of the replacement of a somite row at the pelvic level of a putative mutant chick embryo by a somite row from a non-mutant quail donor: e, external view of such an operated $\mathrm{cn} / \mathrm{cn}$ embryo, at 12 days of incubation, showing the difference in growth between the normally shaped experimental limb $\left(E_{x}\right)$ and the contralateral filiform mutant limb; $\mathrm{f}, \mathrm{g}$, illustration, at two different proximo-distal levels of the lower leg, of such an 11-day experimental limb. The combination of mutant connective tissue cells and non-mutant myogenic cells has led to a normally patterned musculature (Compare with figures $\mathrm{h}, \mathrm{i}$ ) ; $f$, fibula ; $t$, tibiotarsus ; $T$, tendon.

h, i. - II/ustration of the progressive coalescence of the leg muscles, at 71 days of incubation, h, at a distal level, the flexor muscles are completely fused; i, at a more proximal level, the anterior tibialis anterior (TA) and peroneus longus ( $P L)$ muscles, which are the first to be individuated during the patterning sequence, are still individuated, although the intermuscular spaces have shrunk (Compare with figure $f$; figure $4 d, e$ ) 


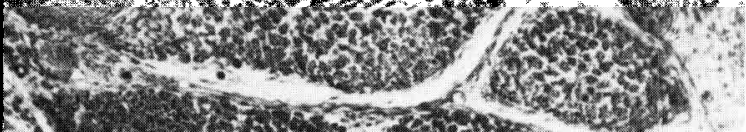
(c)

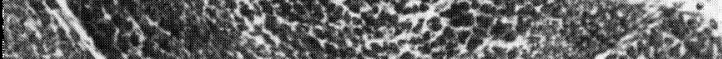

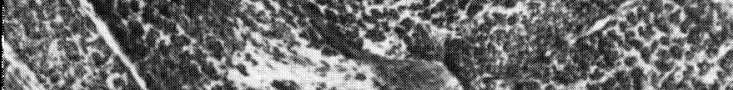

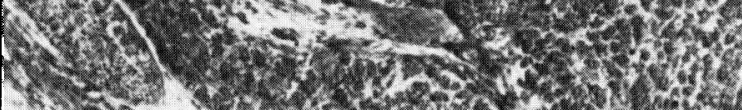

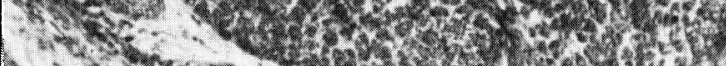

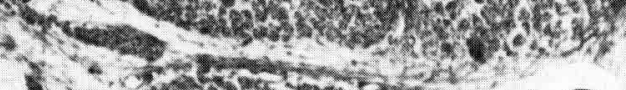

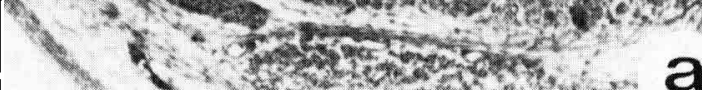
sinction

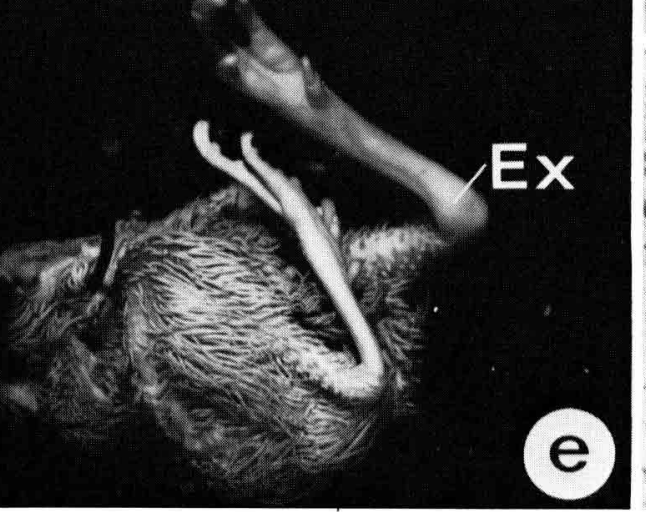

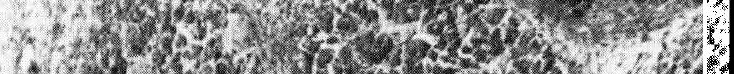

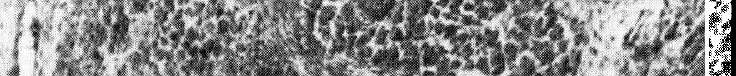
d.

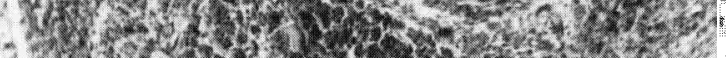

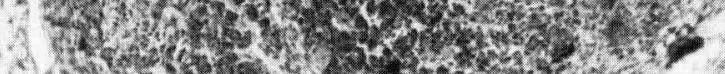
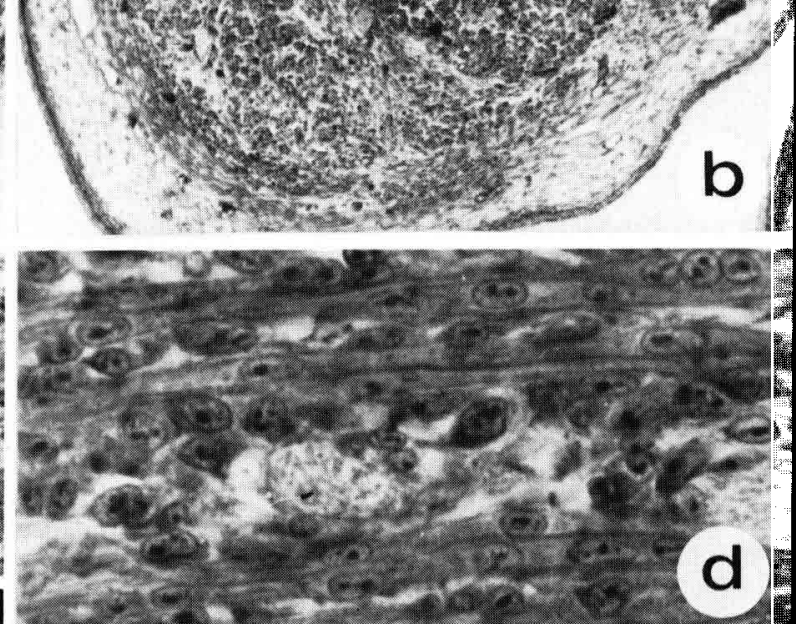

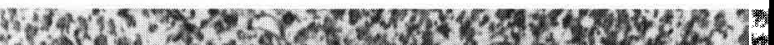

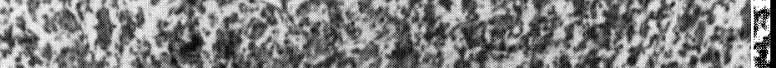

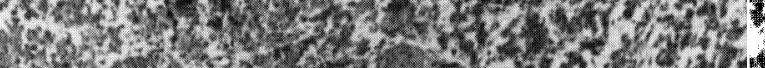
15.

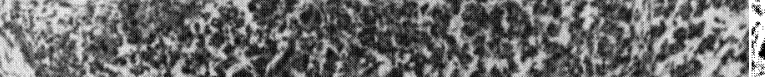

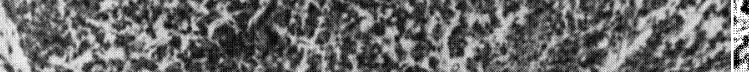
$t=03$ 3.

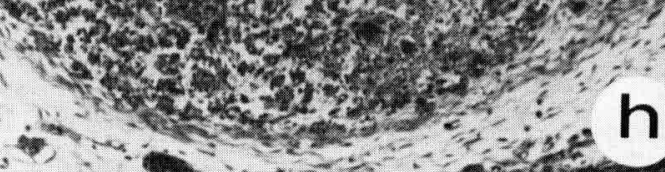
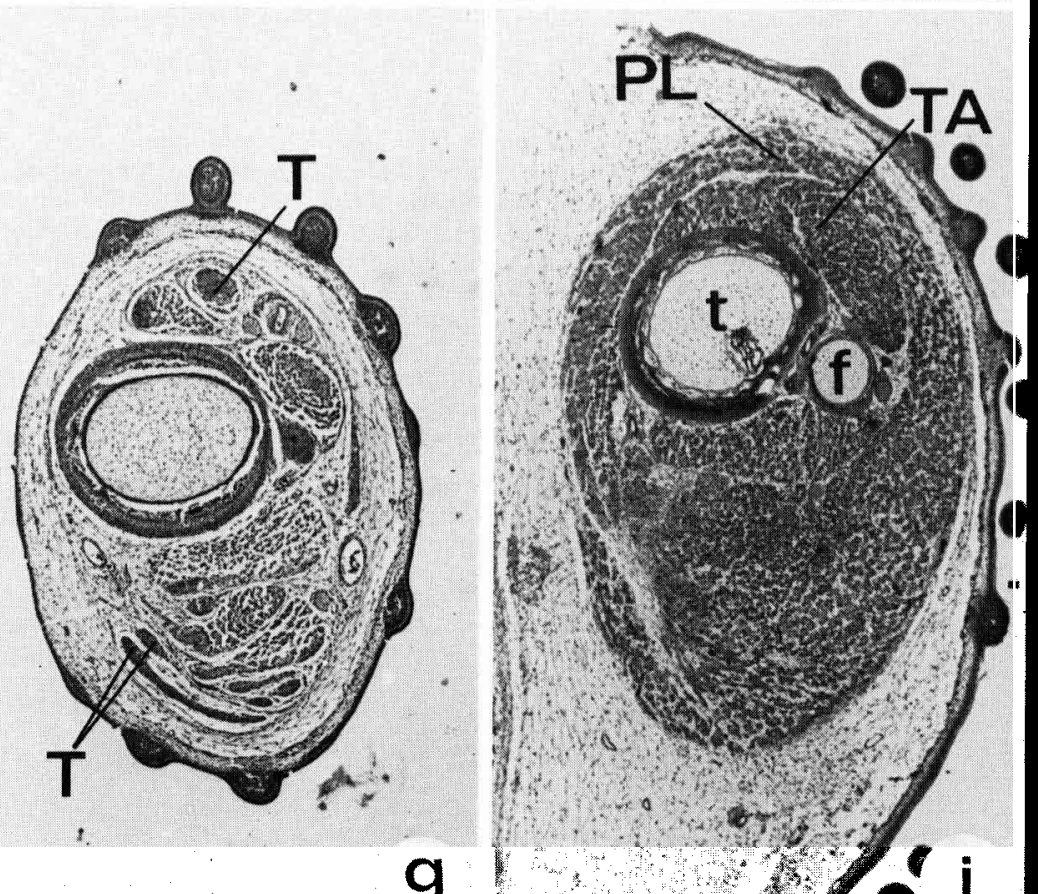
intoses: 0

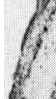

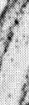
sisting (2) (1.).

$+$
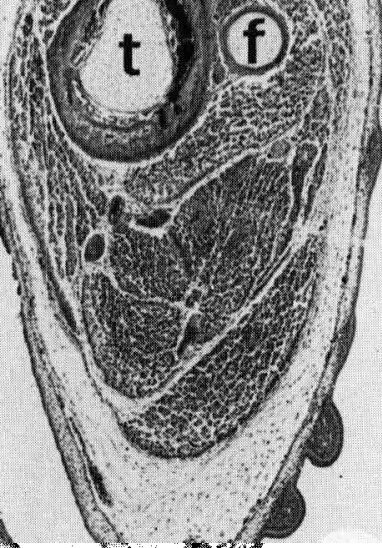

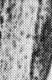


Knowing that the connective tissue cells control the muscle pattern formation, we raised the question of whether these cells, which build the scaffolding of the muscle bulk, are also responsible for the maintenance of muscle architecture. Three types of investigations were undertaken in normal and mutant siblings: a descriptive chronological study of the distribution of the extracellular matrix components, an ultrastructural study of various muscles and an experimental study that brought together mutant with non-mutant partners in the developing limb.

Immunof/uorescent study of ECM distribution. - This analysis dealt with the distribution of type I and type III collagen, fibronectin and laminin (fig. 4) in normal and mutant embryos. It showed that the defect is concomitantly expressed in mutant muscular tissue and tendinous connective tissue. The tendons were mislocated and their development strikingly hindered (fig. $4 a, b, c$ ) ; they progressively disappeared through a dislocation of their interstitial collagen fibres. In the fused muscles, the epi- (compare fig. $4 \mathrm{~d}$ and $4 \mathrm{e}$ ), peri- (compare fig. $4 \mathrm{f}, \mathrm{g}$ and $4 i, j$ ) and endomysial distributions of type I and type III collagen fibres and of fibronectin were aberrant. The abnormalities of the extracellular matrix distribution were not "all or none» phenomena, but accompanied the progressive coalescence of the muscles. Indeed, at the beginning of myopathy, the alterations of the ECM distribution were limited to the coalescent muscles, the still individuated ones having an ECM distribution similar to that of normal muscles, albeit in lesser amounts (Kieny and Mauger, 1984 ; Mauger et al., 1984).

U/trastructural study. - Abnormalities have been detected in wing, leg and breast muscles of every phenotypically mutant embryo, i.e. in muscles derived from the segmenting somitic mesoderm (Kieny et al., 1988a) (fig. 5a, b, c, e). More recent observations show that head muscles [tongue (fig. $5 \mathrm{f}, \mathrm{g}$ ) and jaw (fig. d) muscles], which derive from unsegmenting somitomeres, are affected in a similar way ( $M$. Kieny et al., 1988b), indicating that the myogenic cells from

FIG. 4. - Immunofluorescent studies of the distribution of the extracellular matrix components in normal (a, b, d, f, g, h) and cn/cn mutant (c, e, i, j, k) lower leg musculature.

a to e. - General views of the posterior (a to c) and anterior (d, e) muscles after antitype / collagen labelling. a, 7.5-day normal embryo. The strongly fluorescent areas correspond to the tendons; b, 9.5-day normal embryo. Note the growth of the tendons. Faint labeling corresponds to an intermuscular space (is) ; c, 9.5-day $\mathrm{cn} / \mathrm{cn}$ embryo. Compare the size and the location of the tendons with those shown in figures $a$ and $b ; d, 12.5$-day normal embryo. The space (is) between the tibialis anterior (TA) and the peroneus longus ( $P L)$ muscles contains fibrous material. Each of these muscles has a characteristic perimysial organisation. Note particularly, the herringbone disposition of the label in the TA muscle; e, 12.5-day $\mathrm{cn} / \mathrm{cn}$ embryo; Same muscular area as in figure d. Illustration of the disorganisation of the intermuscular space (is), the absence of the herringbone perimysial patten in the TA muscle and the randomly dispersed fluorescent material in the PL muscle. $T$, tendon of the flexor digitorum longus muscle.

f to h. - 12.5-day norma/ gastrocnemius musc/e. The primary perimysial subdivisions ( $P$ ) appear as continuous veins after anti-type $I$ collagen $(f)$ and antifibronectin $(g)$ labellings. With antilaminin antibody $(h)$ the staining is restricted to a sheath around the clustered myogenic cells.

i to k. - 12.5-day $\mathrm{cn} / \mathrm{cn}$ gatrocnemial muscular area. Illustration of the unorganized, at random distribution of type I collagen (i) and fibronectin (j), and of the weakness and irregularity of laminin deposition. The arrow points to a blood vessel. 


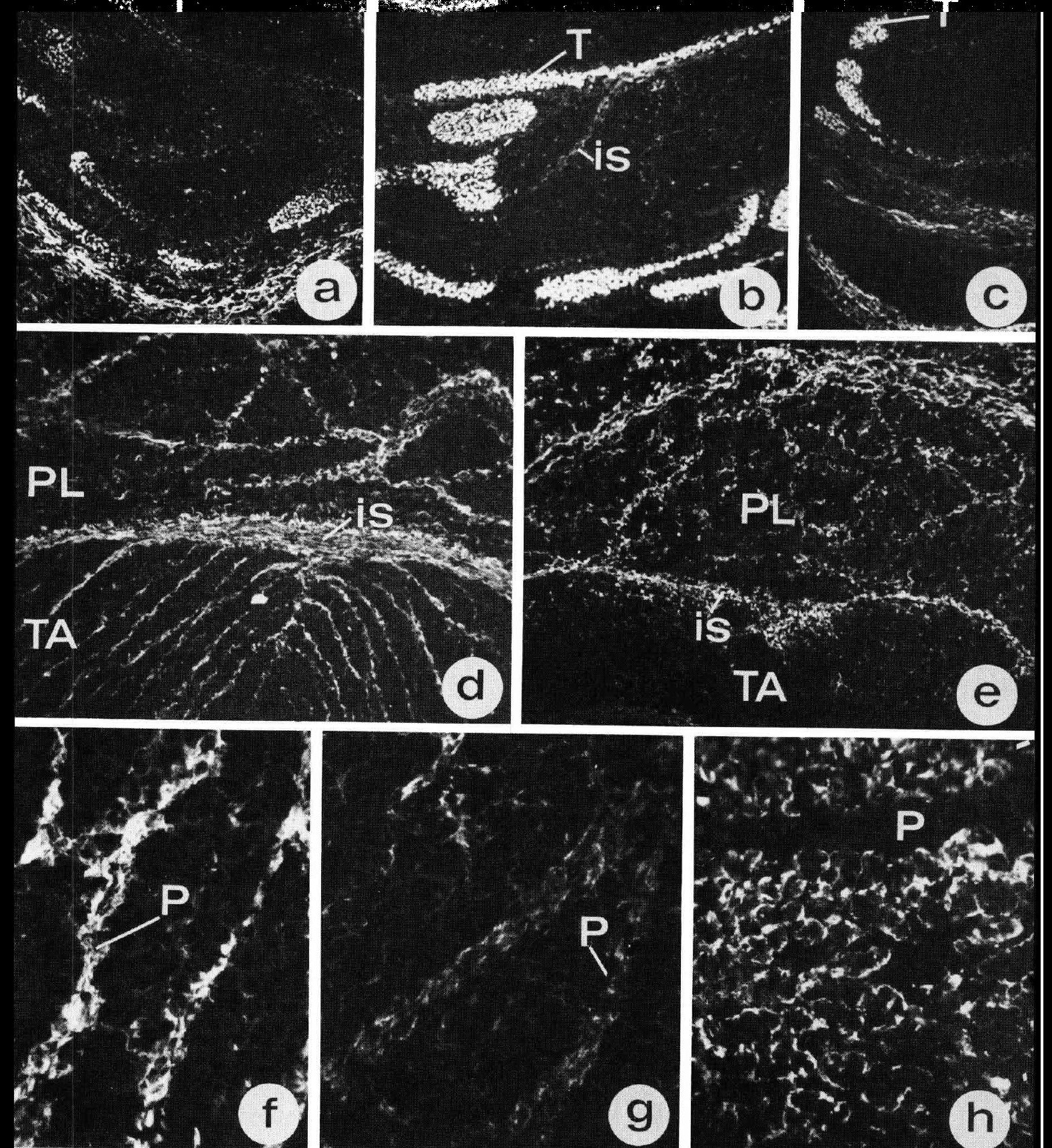


the whole paraxial mesoderm belong to a same, unique lineage. The effects of the cn gene were expressed in the multinucleated cells as fine structural aberrations (fig. 5). Dilatation of the sarcotubular system, partial loss and ill-alignment of the contractile elements and malorganization of the myofibrils were the major anomalies observed from day 7.5 to 18 of incubation. Cell death was a relatively rare event before 18 days in ovo, but at day 20 , it included over the whole population of skeletal muscle cells, as well as satellite cells. The ultrastructural changes did not constitute an abrupt phenomenon. Normal and diseased multinucleated cells always coexisted in the same muscle specimen. It is obvious that, at 7.5 days, only a minority of cells involved in cross striations was pathological. However, as development proceeded, the frequency of the diseased cells increased, and also the extent of malformations in any particular myotube enlarged.

As, at the time when they can be first recognized as belonging to a $\mathrm{cm} / \mathrm{cm}$ embryo, all the myoblasts and the majority of the myotubes or portions of myotubes had a morphologically normal appearance, one can assume that precocious myogenesis was not impaired. According to classical histological images, the differentiation of the myoblasts into the first myotubes (fig. 3c, d) and the myotendinous contacts occur normally. This suggests that, in crooked neck $d$ warf myopathy, the population of early myoblasts (the ones that are receptive to the organizing message of the connective tissue cells) functions normally. The population of later myoblasts does not.

Experimental analysis of the primary target cells. - The morphological and immunocytochemical data offer compelling evidence that the alterations in the ECM distribution precede the alterations of the fine structure of the multinucleated myocytes. At 7.5 days, when only about $10 \%$ of the myotubes are affected cytologically, several gross features attesting the hereditary disorder are already detectable. These are: a tendency of the myogenic clusters to a higher multicellularity (Kieny et al., 1987), a vanishing integrity of the spaces of the flexor muscles and a filling of these intermuscular spaces with type I collagen fibres, resulting from a dislocation of the tendon ECM. In order to determine whether the muscular disorder was due to a misfunctioning of the connective tissue cells, or whether it was primarily myogenic, we performed heterogenetic transplantations between non-mutant quail embryos and mutant chick embryos (Mauger et al., 1983 ; Kieny et al., 1986).

FIG. 5. - Electron microscope images of $\mathrm{cn} / \mathrm{cn}$ skeletal myocytes from 12-day wing-(a, b), 13-day jaw-(d) and tongue-(f,g), 18-day breast-(c) and leg (e) muscle tissue illustrating various cytological alterations: scarceness of myofibrils (a), juxtaposition of normal- and malorganized myofibril-containing myotubes (c), illalignment of myofilaments (e), myofibrillar disarray (d). dilated sarcoplamic reticulum $(S R)$, nuclear inclusion ( $f$, detail in $g$ ) and retraction clot (b). Z, Z-band material. 
The replacement of a somite row at the brachial or pelvic level of a 2-day putative mutant chick embryo by a somite row taken from a non-mutant quail donor led to the development of a normally shaped limb (fig. 3e). Its muscles, the patterning of which was normal and permanent (fig. $3 f, g$ ) were composed of quail myocytes and mutant chick connective tissue cells. Thus the premuscular connective tissue cells are able to function normally provided they get nonmutant myogenic cells to organize. Our experimental series unequivocally established that the deteriorations of the connective tissue system are secondary changes, while the defects of the muscle cell line are the prime manifestation of the mutation (Mauger et al., 1983).

\section{Concluding remarks.}

Limb muscle cells, like all skeletal cephalic and trunk muscle cells, belong to a distinct cell line that originates from the somitic mesoderm. Having once penetrated into the somatopleural mesoderm of the limb bud prior to its bulging out, they progressively aggregate into dorsal and ventral premuscular masses, the successive cleavages of which produce the characteristic muscle pattern of each limb segment.

Just like many other composite embryonic structures, the organogenesis of musculature results from a cascade of tissue interactions between its constitutive partners. To sum up, the following interactions have been demonstrated : 1) The first step of myogenesis, namely the formation of the muscle pattern, is under the control of connective tissue cells, which are responsible for the region-specific architecture of the muscles, whereas the muscle cells themselves are passive partners; 2) the second step, during which the muscle pattern becomes stabilized and muscle morphogenesis is achieved, is under the control of the muscle cells themselves ; 3 ) the course of multinucleated myocyte differentiation is again controlled by the connective tissue cells.

It has become useful to consolidate the concept of a myogenic cell line in other vertebrates and to establish whether or not skeletal musculature ontogenesis in mammals occurs according to the same morphogenetic processes as those in birds. The direct manipulation of mammalian embryos being rather difficult, we begun the exploration of this domain by heteroclass mouse/chick myogenic tissue exchange experiments. Up to now, we have failed in our attempt to create a chimearic skeletal musculature. The mouse myogenic cells, when confronted with a chick environment, were unable to move away from the implantation site (Kieny et al., 1987).

$13^{e}$ Réunion du groupe Développement I.N.R.A. Cap d'Agde, 25-27 mai 1987.

Résumé. Origine et développement de la musculature squelettique chez les Oiseaux.

Cette étude s'adresse à la musculature squelettique des membres. Il y est établi que les deux composantes cellulaires du tissu musculaire, à savoir les myocytes, d'une part, et les cellules conjonctives, d'autre part, n'ont pas la même origine embryologique. Toutes les 
celfules musculaires striées, y compris les cellules satellites, dont d'origine somitique, tandis que les cellules de la charpente conjonctive, ainsi que celles des tendons, dérivent du mésoderme somatopleural. Nos études portent aussi sur les interactions entre ces deux types de cellules au cours de l'organisation spatiale de la musculature. L'analyse des effets d'une hypoplasie héréditaire chez l'embryon de poulet, la mutation crooked neck dwarf, a aidé à la compréhension des mécanismes qui président à la différenciation normale de la musculature.

\section{References}

ARMAND O., KIENY M., 1984. Ontogeny of the myosatellite cell. Arch. Anat. micr. Morph. exp., 73, 75-90.

ARMAND O., BOUTINEAU A. M., MAUger A., PAUTOU M. P., KIENY M., 1983. Origin of satellite cells in avian skeletal muscles. Arch. Anat micr. Morph. exp., 72, 163-181.

ASMUNDSON V. S., 1945. Crooked neck dwarf in the domestic fowl. J. Hered., 36, 173-176.

CAPLAN A. I., KOUTROUPAS J., 1973. The control of muscle and cartilage development in the chick limb: the role of differential vascularization. J. Embryol. exp. Morph., 29, 571-583.

CHEVALLIER A., 1978. Etude de la migration des cellules somitiques dans le mésoderme somatopleural de l'ébauche de I'aile. Wilhelm Roux's Arch., 184, 57-73.

CHEVALLIER A., KIENY M., 1982. On the role of the connective tissue in the patterning of the chick limb musculature. Wilhelm Roux's Arch., 191, 277-280.

CHEVALLIER A., KIENY M., MAUGER A., 1976. Sur l'origine de la musculature de l'aile chez les Oiseaux. C. R. Acad. Sci. (Paris), Sér. D, 282, 309-311.

CHEVALLIER A., KIENY M., MAUGER A., 1977. Limb-somite relationship: Origin of the limb musculature. J. Embryol. exp. Morphol., 41, 245-258.

CHEVALLIER A., KIENY M., MAUGER A., 1978. Limb-somite relationship : effect of removal of somitic mesoderm on the wing musculature. J. Embryol. exp. Morph., 43, 263-278.

CHEVALLIER A., PAUTOU M. P., HARRIS A. J., KIENY M., 1987. On the non-equivalence of skeletal muscle satellite cells and embryonic myoblasts. Arch. Anat. micr. Morph. exp., 75, $161-166$.

CHRIST B., JACOB H. J., JACOB M., 1974, Über den Ursprung der Flügelmuskulatur. Experimentelle Untersuchungen mit Wachtel- und Hühnerembryonen. Experientia, 30, 1446-1448.

CHRIST B., JACOB H. J., JACOB M., 1977. Experimental analysis of the origin of the wing musculature in avian embryos. Anat. Embryol., 150, 171-186.

DIENSTMAN S. R., BIEHL J., HOLTZER S., HOLTZER H., 1974. Myogenic and chondrogenic lineages in developing limb buds grown in vitro. Dev. Biol., 39, 83-95.

FISCHEL A., 1895. Zur Entwicklung der ventralen Rumpf- und Extremitätenmuskulatur der Vögel und Saügetiere. Gegenbauers Morph. Jb., 23, 544-561.

HAMBURGER V., HAMILTON V.L., 1951. A series of normal stages in the development of the chick embryo. J. Morph., 88, 49-92.

JACOB M., CHRIST B., JACOB H. J., 1978. On the migration of myogenic stem cells into the prospective wing region of chick embryos. A scanning and transmission electron microscope study. Anat. Embryol., 153, 179-193.

JACOB M., CHRIST B., JACOB H. J., 1979. The migration of myogenic cells from the somites into the leg region of avian embryos. An ultrastructural study. Anat. Embryol., 157, 291-309.

KIENY M., 1980. The concept of a myogenic cell line in developing avian limb bud, 79-89. In MERKER H. J., NAU H., NEUBERT D., Teratology of the limbs, W. de Gruyter, Berlin.

KIENY M., BOUTINEAU A. M., PAUTOU M. P., GOETINCK P. F., 1988a. Muscular dysgenesis in fowl : ultrastructural study of skeletal muscles in the croocked neck dwarf $(\mathrm{cn} / \mathrm{cn})$ mutant. Biol. Struct. Morph., 1, 15-27.

KIENY M., BOUTINEAU A. M., PAUTOU M. P., JOUK P. S., 1988b. The crooked neck dwarf muscular dysgenesis in fowl is due to a selective alteration of the somitic myogenic cell line. Roux's Arch. Dev. Biol., 197, 49-55. 
KIENY M., CHEVALLIER A., 1979. Autonomy of tendon development in the embryonic chick wing. J. Embryol. exp. Morph., 49, 153-165.

KIENY M., CHEVALLIER A., 1980. Existe-t-il une relation spatiale entre le niveau d'origine des cellules somitiques myogènes et leur localisation terminale dans l'aile? Arch. Anat. micr. Morph. exp., 69, 35-46.

KIENY M., CHEVALLIER A., PAUTOU M. P., 1987. Attempt to produce a chick/mouse heteroclass musculature. Roux's Arch. Dev. Biol., 196, 321-327.

KIENY M., MAUGER A., 1984. Immunofluorescent localization of extracellular matrix components during muscle morphogenesis. I. In normal chick embryos. J. exp. Zool., 232, 327-341.

KIENY M., MAUGER A., CHEVALLIER A., SENGEL P., 1979. Origine embryologique des muscles lisses cutanés chez les oiseaux. Arch. Anat. micr. Morph. exp., 68, 283-290.

KIENY M., MAUGER A., SENGEL P., 1972. Early regionalization of the somitic mesoderm as studied by the development of the axial skeleton of the chick embryo. Dev. Biol., 28, 142-161.

KIENY M., MAUGER A., HEDAYAT I., GOETINCK P. F., 1983. Ontogeny of the leg muscle tissue in the crooked neck dwarf mutant $(\mathrm{cn} / \mathrm{cn})$ chick embryo. Arch. Anat. micr. Morph. exp., 72, $1-17$.

KIENY M., PAUTOU M. P., CHEVAlLIER A., MAUGeR A., 1986. Spatial organization of the developing limb musculature in birds and mammals. Bibl. Anat., 29, 65-90.

LE DOUARIN N., BARO G., 1969. Sur l'utilisation des cellules de caille japonaise comme «marqueurs biologiques» en embryologie expérimentale. C. R. Acad. Sci. (Paris), Sér. D.. 269. 1543-1546.

LEWIS J., CHEVALLIER A., KIENY M., WOLPERT L., 1981. Muscle nerve branches do not develop in chick wings devoid of muscle. J. Embryol. exp. Morph., 64, 211-232.

MAUGER A., KIENY M., 1980. Migratory and organogenetic capacities of muscle cells in bird embryos. Roux's Arch. Dev. Biol., 189, 123-134.

MAUGER A., KIENY M., HEDAYAT I., GOETINCK P. F., 1983. Tissue interactions in the organization and maintenance of the muscle pattern in the chick limb. J. Embryol. exp. Morphol., 76. 199-215.

MAUGER A., KIENY M., GOETINCK P. F., 1984. Immunofluorescent localization of extracellular matrix components during muscle morphogenesis. II. In chick embryos with hereditary muscular dysgenesis (cn/cn). J. exp. Zool., 232, 343-358.

NEWMANS S., PAUTOU M. P., KIENY M., 1981. The distal boundary of myogenic primordia in chimeric avian limb buds and its relation to an accessible population of cartilage progenitor cells. Dev. Biol., 84, 440-448.

NODEN D. M., 1983. The embryonic origins of avian cephalic and cervical muscles and associated connective tissues. Am. J. Anat., 168, 257-276.

NODEN D. M., 1986. Patterning of avian craniofacial muscles. Dev. Biol., 116, 347-356.

PAUTOU M. P., HEDAYAT I., KIENY M., 1982. The pattern of muscle development in the chick leg. Arch. Anat. micr. Morph. exp., 71, 193-206.

SHELLSWELL G. B., WOLPERT L., 1977. The pattern of muscle and tendon development in the chick wing. 71-86. In EDE D. A., HINCHLIFFE J. R., BALLS M., Vertebrate limb and somite morphogenesis. Cambridge University Press.

WACHTLER F., JACOB M., 1986. Origin and development of cranial skeletal muscles. Bib. anat., 29. 24-46. 